\title{
"Sisebutas" en Buenos Aires. Family strips de los años veinte
}

\author{
"Sisebutas" in Buenos Aires: Family strips in the twenties
}

Marcela Gené ${ }^{1}$

\section{RESUMEN}

El artículo trata sobre una de las más exitosas family strips que circularon en la prensa en Buenos Aires en la década del veinte: Pequeñas delicias de la vida conyugal, (Bringin'up father) creada por George Macmanus en 1912 para el emporio periodístico de W.R.Hearst. El argumento apunta a las vicisitudes cotidianas de un matrimonio integrado por una mujer "autoritaria" y un marido "dominado", un topos humorístico que cuenta con una larga tradición en la cultura occidental. Nuestro propósito es analizar, desde la perspectiva de la historia cultural y los estudios warburguianos, su trayectoria histórica en producciones de diversos géneros artísticos, así como indagar en las proyecciones de este topos en las historietas surgidas contemporáneamente y en otras esferas artísticas, como la literatura, el teatro y el cine.

Palabras Clave: Historieta. Mujer dominadora. Snobismo. Argentina. Años veinte. Humor gráfico. Historia cultural.

\section{ABSTRACT}

The article deals with one of the most successful family strips in newspapers circulating in Buenos Aires in the twenties: Pequeñas delicias de la vida conyugal(Bringin'up father) was one of the most succesfull family strips in Argentinian press during the twenties. It was created by George Macmanus in 1912 to the journalistic empire W. R. Hearst. The plot, an humoristic toposwith a long tradition in western culture, focuses into the daily mishaps of a marriage made by an "authoritarian" wife and a "dominated" husband. Based on Cultural Studies perspectives and from a Warburguian approach, this article analyzes the historical trajectory of this topos in productions coming from a very wide range of art genres. It investigates too the projections of this topos in comics emerged simultaneously and in other artistic fields, including literature, theater and film.

Keywords: "Authoritarian" woman. Snobs. Argentine. The twenties. Graphic humour. Cultural history.

\footnotetext{
${ }^{1}$ Universidad de Buenos Aires.
} 
En el Buenos Aires de mediados de los años veinte, la sola mención del nombre "Sisebuta" bastaba para evocar risueñamente la figura de una esposa mandona $y$, en consecuencia, un marido resignado. El matrimonio de Trifón y Sisebuta era el protagonista de la tira Pequeñas delicias de la vida conyugal, la primer family strip aparecida en diarios de alcance masivo que $L a$ Nación comenzó a publicar diariamente desde $1920^{2}$. Creada por George MacManus en 1912 para uno de los diarios del imperio Hearst, Jiggs \& Maggie eran una pareja de inmigrantes irlandeses que se enriquecen repentinamente y tratan de acomodarse a los cambios que impone la nueva vida en tierra norteamericana. Mientras Sisebuta pugna por pertenecer a la clase alta y se esfuerza en refinarse, Trifón intenta eludir las exigencias de su esposa para transformarlo en un hombre "de sociedad". Así, las constantes desavenencias del matrimonio marcan el ritmo de la historia, en situaciones que se reiteran con el mismo resultado: ella logra imponer sus caprichos y él termina casi siempre con un ojo morado.

Tal fue el impacto de Pequeñas delicias.., aún entre quienes no eran habituales lectores del matutino, que poco después comenzaron a publicarse historietas con el mismo argumento y hacia mediados de la década, los avatares de esta familia snob era ya un tópico consagrado del humor en Buenos Aires, que superó el marco de la gráfica para proyectarse en otros medios como el cine y el teatro. ¿Por qué resultaba una fórmula tan exitosa? ¿Qué mecanismos ponía en marcha en los lectores la repetición de situaciones con el habitual desenlace de un Trifón apaleado? ¿era acaso la inversión de los roles de género, la instauración de la potestad femenina que la vía humorística permite desplegar con exageración y desenfado, aquello que despertaba la sonrisa frente a la página del diario y la carcajada franca cuando se veía al "matrimonio" en escena?.

Aunque los seguidores de la tira creyeran estar frente a un argumento novedoso, lo que la pluma de MacManus revivificaba era un topos $^{3}$ humorístico de muy larga tradición en la historia de la cultura de occidente, transmitido a través de generaciones y diversos géneros artísticos, sujeto, en ese transitar, a reelaboraciones gráficas y destilaciones de sentido. Por cierto Sisebuta se inscribe en una genealogía histórica de "mujeres de mal genio" - piénsese en la Jantipa de Sócrates como una insigne predecesora-, así como Trifón forma parte de una estirpe de congéneres ficcionales dominados por esposas y suegras.

En nuestra opinión, esta fórmula ha reactivado su energía expresiva en el siglo XX, resurgiendo en el campo de la historieta difundida en los medios masivos y en otros espacios de entretenimiento popular, como la comedia teatral y cinematográfica, provocando similares efectos de hilaridad que en nuestros antepasados. En este sentido, nuestra propuesta consiste en analizar este topos en la doble dimensión que metodológicamente postula la historia cultural: en

\footnotetext{
${ }^{2}$ Se publicó en La Nación hasta mediados de los años 80 y en EEUU hasta 1993.

3 Burucúa define topos como un " lugar común" del repertorio iconográfico que utiliza una escuela o una tradición artística [...] que representa instituciones, prácticas e ideas generales de una cultura, que puede migrar entre tradiciones regionales o nacionales, de sitio en sitio, de época en época [...]. Burucúa (2007, p.17-18).
} 
primer lugar, en el nivel de la diacronía, recorrer su trayectoria histórica recuperando ejemplos de las representaciones visuales (grabados, estampas populares) que configuren un elenco de expresiones previas, así como en otras producciones culturales como la narrativa y el teatro. Luego, en el nivel de la sincronía, examinar las proyecciones de esta fórmula en otras empresas humorísticas y en otras ramas artísticas contemporáneas (SCHORSKE, 1981, p. 15-16; CHARTIER, 1992, p. 41-42). Asimismo, las investigaciones de José Emilio Burucúa sobre la o las Pathosformeln ${ }^{4}$ que, entre los siglos XVI y XVII concentraron la representación de lo cómico y la risa, han sido altamente inspiradoras de nuestro trabajo. Sus bellos y eruditos libros publicados en los últimos años, particularmente La imagen y la risa, nos han brindado interesantes pistas, tanto desde el punto de vista metodológico - tributario del de Aby Warburg- como en el corpus de grabados seleccionados (BURUCÚA, 2001, 2005, 2007). Varios de los ejemplos mencionados por Burucúa han resultado piezas medulares para iniciar la reflexión sobre el tema planteado en este artículo.

\section{Humor en el diario La Nación}

En los años veinte, las tiras cómicas comienzan a proliferar en los diarios porteños, una incorporación tardía si se tiene en cuenta la amplia circulación de estas producciones en revistas y magazines desde la primera década del siglo. Caras y Caretas, pionera en tantos aspectos, también lo fue con la publicación en 1912 de "Viruta y Chicharrón", una versión vernácula de "SpareRibs \& Gravy" de George MacManus, cuya autoría se atribuyó erróneamente a otro dibujante. Sin embargo, no fue por la historieta de los dos amigos fracasados que MacManus se conoció en Buenos Aires sino por la llegada de Pequeñas delicias.., a La Nación, que aseguró al autor, al diario y a la empresa patrocinadora de la tira, un éxito inusitado ${ }^{5}$.

La fama se extendía paralelamente por Europa y otros países de Latinoamérica (VERGUEIRO, 2003). ${ }^{6}$ Mexicanos, italianos, españoles se solazaban por entonces con estos personajes, rebautizados a la usanza de cada país $^{7}$, gracias a la monumental empresa exportadora

\footnotetext{
${ }^{4}$ Burucúa define el concepto de Pathosformel como "un conglomerado de formas representativas y significantes, históricamente determinado en el momento de su primera síntesis, que refuerza la comprensión del sentido de lo representado mediante la inducción de un campo afectivo donde se desenvuelven las emociones precisas y bipolares que una cultura subraya como experiencia básica de la vida social", José Emilio Burucúa, (2007, p.13-16).

${ }^{5}$ Bringin'up father o Jiggs and Maggie, llegó a ser una de las historietas más exitosas y longevas de todos los tiempos, comparable a "Mutt y Jeff" de Budd Fisher o a "Blondie" de Chic Young.

${ }^{6}$ Según Waldomiro Vergueiro, en el proceso de "globalización" encarado por los Syndicates, ningún tema resultaba tan universal como las situaciones ocurridas en el ambiente familiar. El autor considera que la difusión en el exterior de family strips, transplanta el american way of life en otras sociedades, con las implicancias ideológicas que ello supone. Disentimos en este punto, ya que las razones de que las tiras se instalaran tan exitosamente entre públicos diferentes, presume la existencia de problemáticas afines en sociedades diversas en el mismo tiempo histórico. Waldomiro Vergueiro (2003).

${ }^{7}$ En España recibió distintos nombres: "Don Canuto Picabia y doña Petronila”," Don Cirilo Caliqueño", "Don Plácido", "Zabulón y su familia", "Pancho y Ramona" - uno de los más frecuentes- ," Peripecias de don Pancho" y "Educando a papá", traducción del título original; en México, "Pancho y Ramona”; en Brasil, en el diario O Globo, con el nombre de “
} 
de funnies a todo el mundo, el King Features Syndicates, fundada por William Randolph Hearst en 1914 y que encontró en Moses Konigsberg el mejor brazo ejecutor (KONIGSBERG, 1941, p. 448). ${ }^{8}$ La fundación del Syndicate requirió de la producción acelerada de comic strips de modo que los dibujantes se veían exigidos en la entrega de varias tiras en simultáneo, la mayoría de aparición diaria, sumadas a las especiales para la sección dominical, además de las de exportación. La alta demanda de trabajo, no suponía ninguna explotación sino que era remunerada con creces y casi todo el elenco inicial de jóvenes humoristas contratados por Hearst, incluido MacManus, vivían como magnates. Entre los centenares de historietas vendidas a numerosos medios periodísticos, "Jiggs \& Maggie" o "Trifón y Sisebuta", alcanzó enorme popularidad en "Shangai, Buenos Aires y Estocolmo", según afirmaba Konigsberg, y hacia 1928 circulaba en más de 600 comunidades estadounidenses, "la mayor lista de clientes jamás obtenida por un cómic" (KONIGSBERG, 1941, p. 449). La Nación fue uno más de aquella larga lista.

Había buenas razones para que el diario se aggiornara. Lejos del atractivo visual que otros medios periodísticos ostentaban al despuntar los veinte, La Nación era un diario "serio y grave". El gran formato limitaba las maniobras del usuario; la puesta en página respondía a un riguroso encolumnado que ceñía la ya de por sí apretada tipografía, que hacía de cada página una superficie agrisada cuya monotonía era apenas interrumpida por un título, como sucedía por otra parte en la mayoría de los periódicos de la época. No obstante, La Nación habría de resignar semejante "sobriedad" gráfica, aguijoneado por la creciente modernización de la prensa y la competencia entre los medios. Si W.R. Hearst o su colega Pulitzer eran el espejo donde debían mirarse los empresarios del periodismo si querían ser "modernos", la inclusión de materiales visuales en el diario, ya fuesen fotografías, publicidades, ilustraciones o tiras cómicas, era de rigor para dinamizar la lectura, acorde con los nuevos tiempos de intensa apelación sensorial. Hubo, no obstante, algunas resistencias iniciales por parte de los lectores, refractarios a la intromisión de una historia banal en medio de las sesudas editoriales, pero pronto la tira se transformó en un hábito cotidiano, esperándose día a día una nueva y arriesgada aventura de Trifón, según comentaba la nota aparecida en 1926:

Desde hace más de cinco años nuestros lectores vienen regocijándose con las andanzas, ya profundamente cómicas, ya fuertemente grotescas o impregnadas de un dejo de melancolía, de don Trifón Opez, el popular personaje creado por George McManus. A la distancia recordamos todavía la oposición que en una parte de nuestros lectores encontró la innovación que significaba el hecho de incluir un material

Pafúncio y Marocas"; en Chile como "Don Fausto y soña Crisanta”. En Italia, apareció inicialmente en Il Corriere dei Piccoli, con el nombre de "Arcibaldo e Petronilla" y más tarde como "Zenobaldo y Domitilla". Manfredo Guerrera, Storia del fumetto, Autori e personaggi dalle origini a oggi, Tascabile Economici Newton, Roma, 1995.

${ }_{8}^{8}$ La lista de clientes del King Features Syndicate hacia 1919 era de 1200 medios periodísticos en todo el mundo, en 27 lenguas diferentes. El King Features, fundado en 1915 bajo la dirección de Konigsberg, sucedió al Newspaper Feature Service, que fue en 1913 la primera organización de Hearst para la distribución de cómic strips entre los periódicos de Estados Unidos. 
de esa especie en nuestro diario. Un concepto un poco arcaico de lo que debe ser el periodismo hizo, en efecto, que al principio resultase chocante la publicación de aquellos dibujos en un diario tradicionalmente serio $y$ grave. Pero no transcurrió mucho tiempo sin que se advirtiese que esa seriedad y esa gravedad, características, sobre todo, de la columnas editoriales y de ciertas secciones de señalado matiz intelectual, no eran de ningún modo incompatibles con la nota artística destinada a poner en los labios del lector todas las mañanas, antes de emprender las tareas del día, una sonrisa. Así, lo que alarmó al principio adquirió bien pronto una popularidad grande... El fondo de interés humano que revestían las historietas hizo, por lo demás, que éstas cautivasen por igual a grandes y a chicos. No hay en nuestro país un ejemplo equivalente de que lo destinado a los lectores adultos atrajese en igual proporción a los lectores infantiles. ${ }^{9}$

Sin embargo, la publicación de Pequeñas delicias..., no sólo incorporaba un matiz en la monolítica página y estampaba una sonrisa en los labios del lector cada mañana, sino que difundía una de las sagas cómicas que, en Buenos Aires, daría que hablar.

\section{¿Pero es cierto que las mujeres pertenecen al sexo débil? ${ }^{10}$}

Una vez que se ha pensado en un hombre grande y en un hombre pequeño, es muy fácil hacer el resto ${ }^{11}$

El soliloquio de Trifón conlleva una toma de conciencia: la siempre mentada debilidad del sexo femenino no se aplicaba al caso de su esposa. El golpe de fortuna que lo transformó en millonario, lo sumió a la vez en la plena infelicidad conyugal. Sisebuta, la buena compañera de los tiempos en que ambos eran trabajadores pobres, librada ahora a la carrera de ascenso social, le reprochaba constantemente su incapacidad de adecuarse a un medio hacia el que el hombre no mostraba ningún interés en pertenecer. Trifón no renunciaba a sus costumbres y sobre sus inocentes "transgresiones" como jugar a las cartas con sus amigos y comer guiso de carne con repollo-, caía todo el peso de la "ley": la pendenciera consorte era capaz de encerrarlo para aislarlo de la gentuza que lo mantenía vinculado a su rústico origen, aunque él siempre se las ingeniaba para eludir el control, descolgándose por la ventana, caminando en equilibrio sobre los cables de teléfono y ganando la libertad por algún callejón lateral, que siempre lo dejaba a pocos pasos del bar de Dinty Moore (HARVEY, 1994, p. 62). ${ }^{12}$

\footnotetext{
${ }^{9}$ La Nación, 30 de julio de 1926. La itálica es nuestra.

${ }^{10}$ Trifón, en una de las tiras

${ }^{11}$ Samuel Johnson, a propósito de la obra de Jonathan Swift, Los viajes de Gulliver.

${ }^{12}$ James Moore, dueño de una taberna frecuentada por MacManus, es, con el nombre de "Dinty" uno de los principales personajes de la tira. Su taberna es el espacio de sociabilidad y solidaridad masculina, -como el bar de Moe para Homero Simpson- ya que Dinty apaña a Trifón cuando se escabulle de Sisebuta. El éxito de la "Dinty's tavern" en la historieta
} 
Figura 1 - Pequeñas delicias de la vida conyugal

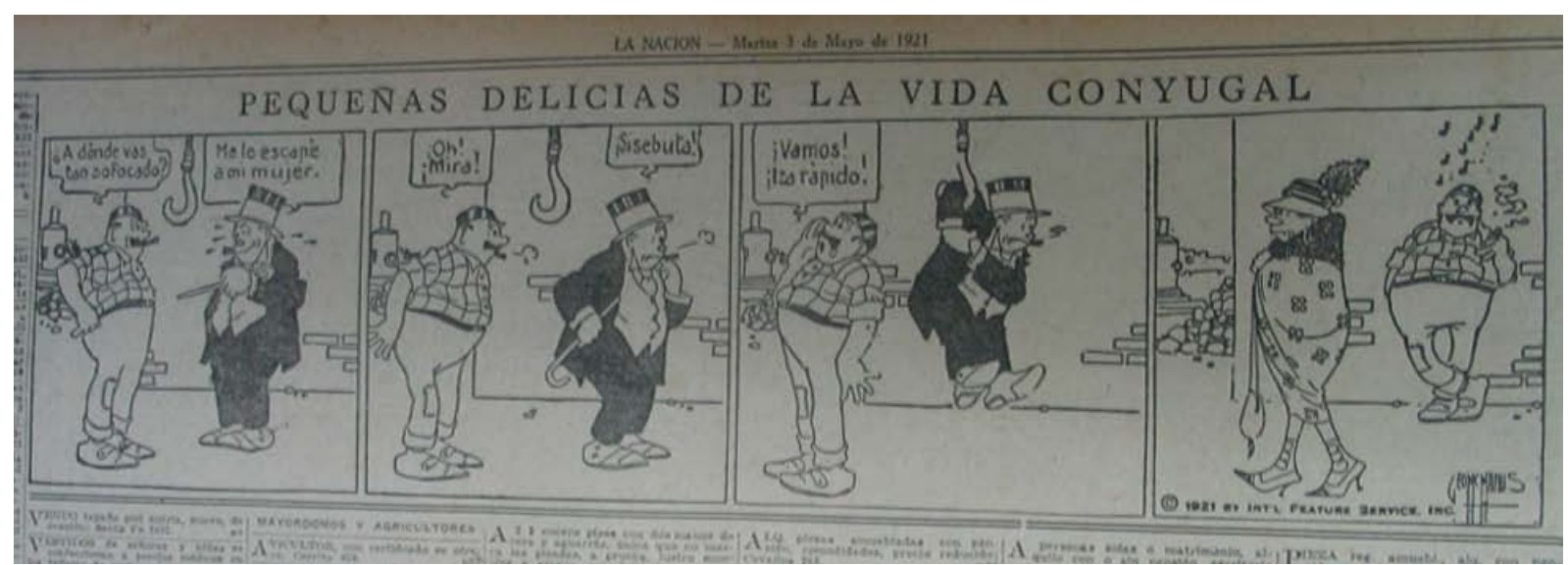

Fonte: La Nación, 3 mayo 1921.

A su regreso, lo esperaba una nube de enseres de cocina volando hacia su cabeza o Sisebuta, agazapada, blandiendo el palo de amasar. Pocas cosas parecen haber identificado con tanta precisión el poder femenino como este utensilio, que trocó su significado como atributo de un ama de casa hacendosa por el de arma letal para díscolos maridos.

Figura 2 - Pequeñas delicias de la vida conyugal

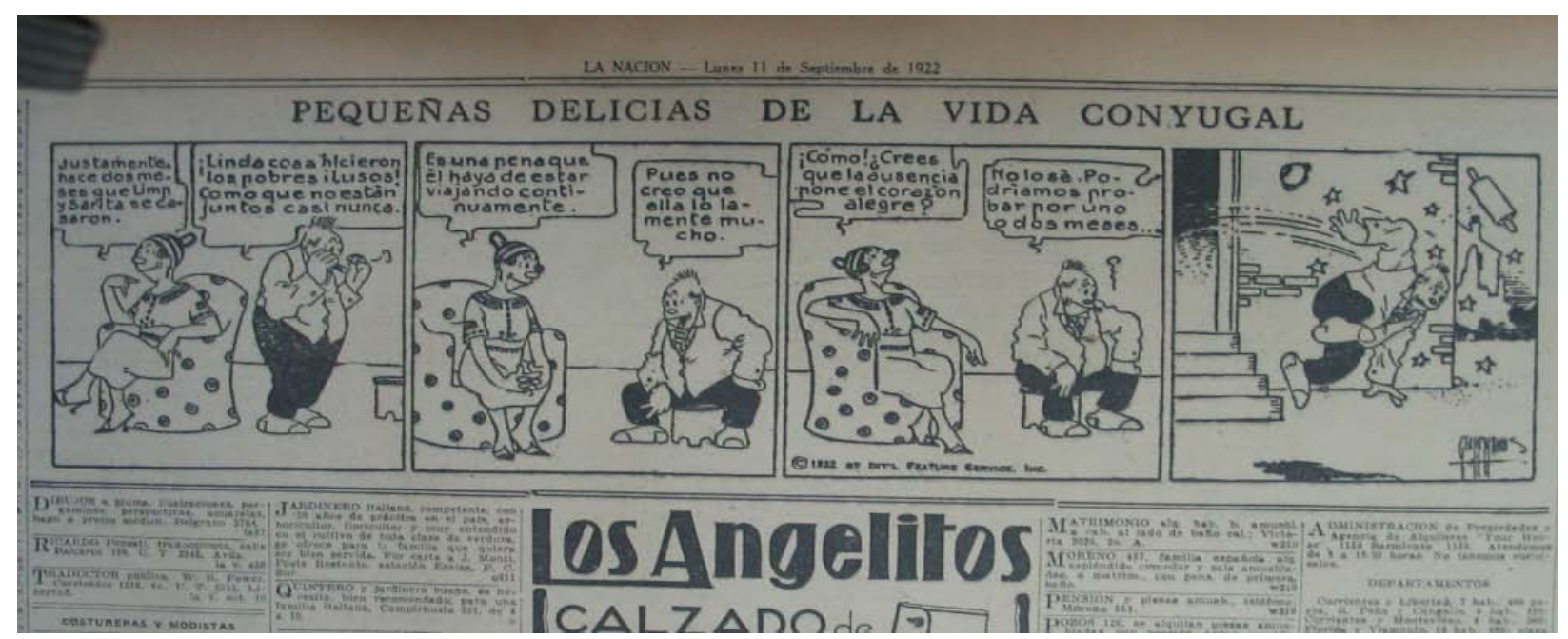

Fonte: La Nación, 11 set. 1922, p. 4

motivó el cambio de nombre del establecimiento real y Moore amasó una fortuna imponiendo la marca "Dinty Moore's" a una línea de productos de carne enlatada. 
Es que con el correr de los años, el personaje de Sisebuta se había vuelto más intolerante y agresivo. Aquélla que en la primera década se desmayaba por la humillación social a la que la sometían las torpezas de Trifón, en la siguiente, cuando la historieta llega a La Nación, la vergüenza se transforma en ofuscación. Éste fue, en los 40 años en que MacManus realizó la serie, el único cambio introducido por el dibujante. La radicalización del carácter requería la acentuación del contraste físico entre los cónyuges. Así, la regordeta mujer de los años iniciales, deja paso a una de torneada silueta, alta y fibrosa, aunque era feísima ${ }^{13}$, mientras Trifón, otrora corpulento, como correspondía a un peón de albañil, se vuelve más bajo y ancho. Resultaba ridículo que ella desplegara semejante destreza frente a un hombre alto y forzudo: la retórica visual de la historieta requería que Trifón luciera como si Sisebuta pudiera intimidarlo, convención humorística usualmente explotada por su capacidad de expresar la asimetría de poder (GOMBRICH, 1967, p. 167-168). Cuando el hombre es maltratado por la mujer, como en nuestro caso, es la inversión de los patrones de género lo que desata el efecto cómico.

Como señalamos inicialmente, se trata de un topos muy antiguo en la cultura de occidente, cuyos orígenes pueden rastrearse en la primera modernidad, y es posible que en su constitución histórica se articulen algunas de las variantes de las Pathosformeln cómicas identificadas Burucúa. Por un lado, la variante invertida de la Pathosformel de la majestas -el señorío o el dominio (BURUCUA, 2007) ${ }^{14}$ - que instaura el trueque de papeles y funciones socialmente establecidos: mujeres, niños y animales asumen el rol del personaje que ejerce la dominación. Es el "mundo del revés", del orden subvertido, del dominador dominado, plasmado en satíricas imágenes artísticas y literarias, aquello que suscita la risa de irreverencia, - la risa carnavalesca, según las categorías formuladas por Peter Berger-, liberadora de secretas rebeldías y pasiones reprimidas (BERGER, 1999). Por otro lado, el caso de la inversión de una Pathosformel previa, la de la Ninfa estudiada por Warburg (WARBURG, 2005). Se trata de la antiNinfa,"contrafigura de la joven de movimiento grácil o desenfrenado [...] señal de la dinámica de una vida nueva y expansiva"; la que alguna vez pudo haber sido etérea y fascinante, se ha vuelto rústica, ha perdido sus formas y ha adoptado actitudes masculinas, ya no seduciendo a los hombres sino dominándolos con fiereza (BURUCUA, 2007, p. 78).

En un recorrido sumario a través de la literatura y la estampa populares desde el siglo XVI al XIX, como el que planteamos a continuación, encontraremos algunos ejemplos que nos permiten balizar el camino que conduce a nuestra moderna Sisebuta de historieta y otras señoras de mal genio. Examinemos los casos, aún a riesgo de que nuestro panorama histórico resulte incompleto.

\footnotetext{
${ }^{13}$ MacManus (apud HARVEY, 1994) la describió como “ compuesta por todas las bellas mujeres del mundo... cuando están enojadas".

${ }^{14}$ El príncipe en el trono, administrando justicia; de pie, armado, con emblemas de mando, saludando a las tropas; el jinete que domina su cabalgadura.
} 
La cuestión de la autoridad femenina ya acechaba las mentes de los hombres de la Edad Media y el Renacimiento. De Chaucer al teatro isabelino, de Rabelais al teatro y la narrativa franceses del XVII y XVIII, cierta recurrencia al tema de la "mujer dominadora" evidencia la vitalidad del mismo en sede literaria a través de varios siglos. Para algunos de los personajes de ficción, tal comportamiento para con los hombres es un dilema sin solución. Al respecto, uno de los relatos de los peregrinos de Canterbury trata sobre el condenado a muerte que, para salvar su vida, debía desvelar el misterio acerca de "qué es lo que las mujeres desean". Al cabo de cierto trajín, el pobre diablo encuentra por única y poco convincente respuesta "[que] en general las mujeres desean ejercer autoridad tanto sobre sus esposos como sobre sus amantes y tener poder sobre ellos", conclusión que, para su sorpresa, satisfizo a tal punto a la reina y su femenina corte que "ni una sola matrona, doncella o viuda en todo el tribunal contradijo tal afirmación (CHAUCER, 1484). El condenado mereció entonces conservar la vida.

A Panurgo, el pícaro y cobarde amigo de Pantagruel, la violencia que las mujeres ejercen sobre los hombres le produce un temor paralizante. Las desopilantes cavilaciones frente al matrimonio que desea realizar disponen al gigante a consultar las llamadas "suertes virgilianas", con resultados poco edificantes para su compañero: las dudas y temores que lo atormentan parecen justificarse ante la sospecha de que probablemente, su mujer lo cornificará, lo molerá a palos y, además, lo despojará de todo (RABELAIS, 1546, p. cap.XII).

Finalmente, hubo quienes tomaron el problema del mal genio femenino como un desafío del que podía salirse victorioso. En la comedia de Shakespeare, Catalina es, a los ojos de Petrucchio, comparable "a la Jantipa de Sócrates, o peor" (SHAKESPEARE, 2002). La esposa del filósofo, famosa por maltratarlo en público, devino en estereotipo literario de la mujer violenta y su figura fue evocada en la obra shakespeariana como patrón popularmente conocido para medir el capricho y el autoritarismo femenino, aunque el mancebo paduano fue más afortunado en la "domesticación” de su mujer que el filósofo griego y, su estrategia, menos cruenta que la del joven protagonista del cuento de Don Juan Manuel, fuente literaria de la obra de Shakespeare. ${ }^{15}$

La transposición de estos topoi del campo de la literatura al figurativo encuentra en la gran producción de grabados entre el siglo XVI y el XIX un terreno fértil para la exploración. Algunas de las estampas halladas por Burucúa constituyen valiosas referencias para nuestro análisis (BURUCUA, 2007) ${ }^{16}$. Se trata de representaciones de feroces combates entre mujeres, -o entre hombres y mujeres- que aluden metafóricamente al poder sexual, y a un indisimulado apetito femenino por el miembro viril. Uno de los grabados representa la lucha por las bragas masculinas, con la pertinente invocación al dios Príapo (BURUCUA, 2007, p. 57-58) ${ }^{17}$ y el otro, la

\footnotetext{
${ }^{15}$ Referimos al cuento 31, "Lo que sucedió a un mancebo que casó con una muchacha muy rebelde”, del Libro de los ejemplos del Conde Lucanor y de Patronio de Don Juan Manuel, 1330-1335.

${ }^{16}$ Marolles, M. de, abbé de Villeloin, Catalogue de livres d'estampes et de figures en taille douce. Avec un dénombrement de pièces qui y son contenues. Fait à Paris en l'année 1666. Cabinet des Estampes de la Bibliothèque Nationale de France.

${ }^{17}$ Talla dulce de fines del siglo XVI. El título de la estampa en latín rezaba: "Ay de ti, Príapo si resguardas ahora lo que habitualmente has cubierto".
} 
violenta gresca entre Margot, la aristócrata y su burguesa rival por la posesión de una sugerente morcilla, con la que una de ellas golpea la cabeza de su contendiente. ${ }^{18}$

Figura 3 - Duel de l'andouille.

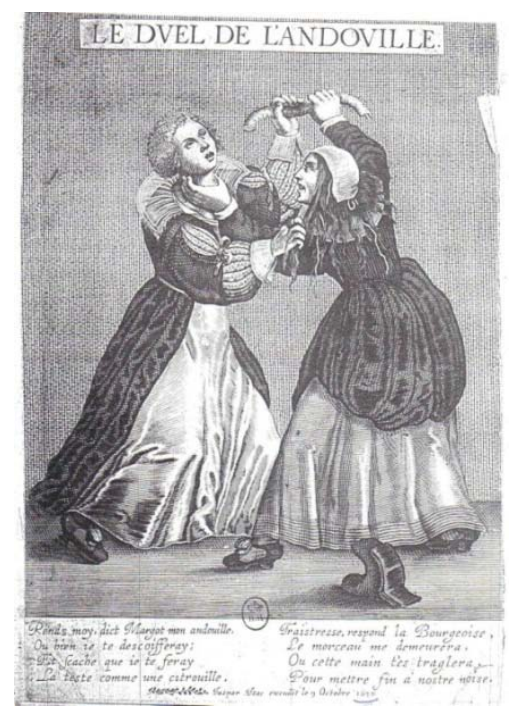

Fonte: Duel de l'andouille, Iaspar Isac, 1634

Un tercer grabado, de mediados del XVII,-“Aut amat, aut odit Mulier”- muestra a mujeres de aire viril amenazando a los consortes que suplican piedad arrodillados, mientras una de ellas blande una maza de madera (¿predecesora del palote?) y otra levanta el puño contra quien lidia por quitarle los interiores masculinos ocultos bajo las polleras.

Figura 4 - Aut amat, aut odit Mulier.

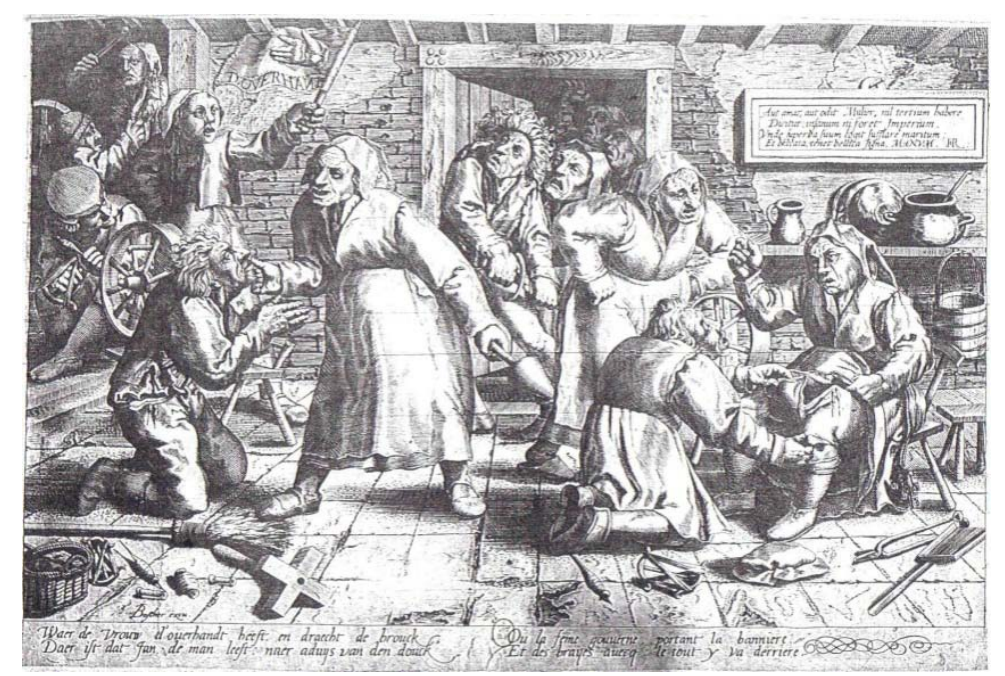

Fonte: Aut amat, aut odit Mulier, mediados del siglo XVII

${ }^{18}$ Duel de l'andouille (Duelo de la morcilla), grabado de Iaspar Isac, 1634. (BURUCÚA, 2007, p.57-58). Agradezco al profesor Burucúa el conocimiento de estos grabados. 
Combatir por los calzoncillos, batirse a duelo por una morcilla: un tema que, a juzgar por la cantidad de estampas producidas en Francia en los siglos XVIII y XIX, revela el persistente interés de varias generaciones de grabadores e impresores, en respuesta a una demanda que se infiere sostenida en este período. En el curso de un siglo, la representación fue depurándose de objetos, personajes y acciones simultáneas, para transformarse en una más ordenada composición que gravita en torno del elemento en disputa. Ya en el XIX, la talla dulce "Ambition de la femme pour parvenir á la maitris de la culotte" realizada en el taller de los Basset,imprimeur el padre, graveur el hijo-, retoma la cuestión de la pugna marital, ambientada en un interior burgués.

Figura 5 - Ambition de la femme pour parvenir à la maitris par la culotte.

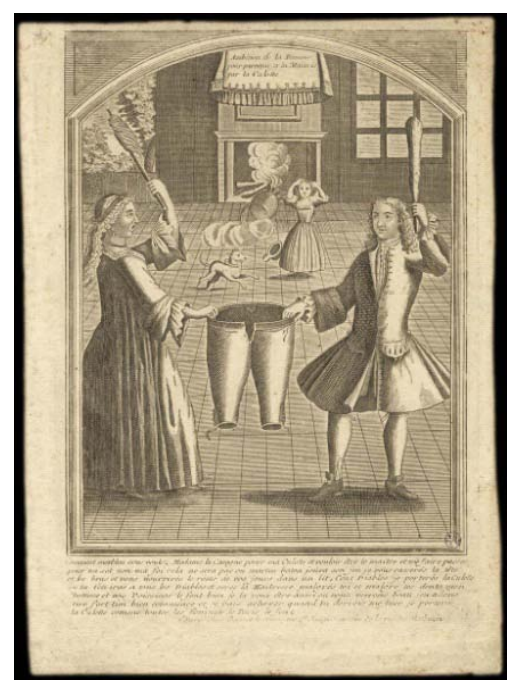

Fonte: Ambition de la femme pour parvenir à la maitris par la culotte, Taille-douce, André Basset ( impresor, editor), Basset le Jeune (grabador), 1750-1785.

La pareja, amenazándose mutuamente con utensilios domésticos, tira de la prenda con tal equilibrio de fuerzas que resulta difícil prever quien saldrá victorioso, a pesar de que el diálogo reproducido al pie de la estampa no deja lugar a dudas:

Comment morbleu vous voulez Mme. la Carogne porter ma culotteet vouloir être le maître et me faire passer pour un sot non ma fois cela ne sera pas ou martin baton joura son jeux et je vous casserés la tête et les bras et vous nourrirés le reste de vos jours dans un lit. / Cent diables je porterés la culotte et tu t'en iras à tous les diables et seres la Maîtresse malgrés toi et malgré tes dents mon hôtesse et nos voissines le font bien et je la veux être aussi [...] je porteres la culotte comme toutes les femmes de Paris le font " (sic). 
Quizás sea éste un modelo de representación cristalizado del tema si se considera la cantidad de estampas impresas en el establecimiento Pellerin que han circulado en el siglo XIX. ${ }^{19}$ Nos referimos a la serie "La grande querelle du ménage" cuya primera tirada se realizó en 1837 y fue reimpresa, con intervalos de siete a diez años, hasta $1880 .{ }^{20}$ La imagen es esencialmente la misma, aunque en cada versión se introdujeron ligeras variantes, además de las marcas de estilo de los distintos grabadores que intervinieron en el curso de los años. El texto al pie se repite en casi todas las estampas: « Un mari déculotté de la sorte/ est un homme qu'on met à la porte [...] et cette grande querelle là/ longtemps encore on reparlera ". ${ }^{21}$

Figura 6 - La grande querelle du ménage.

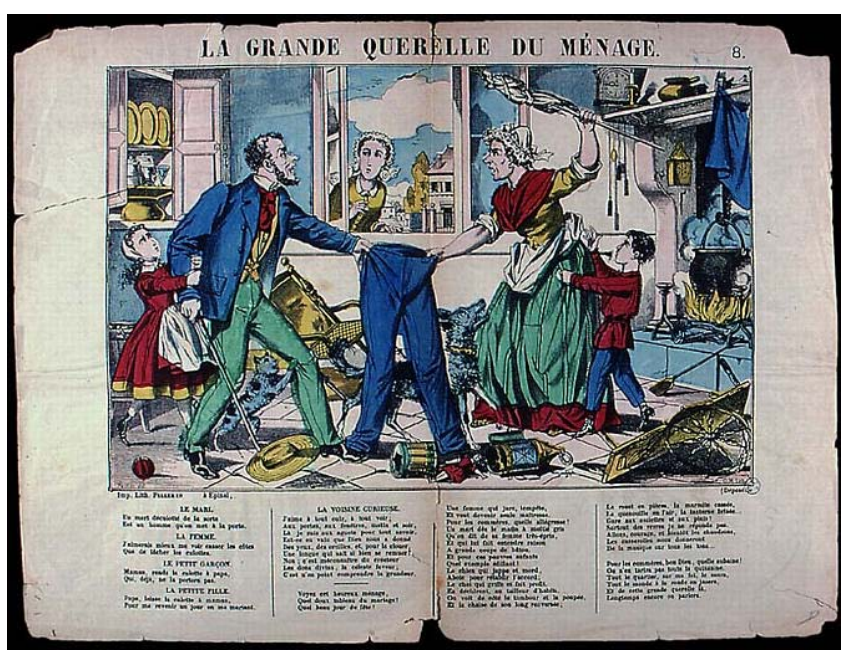

Fonte: La grande querelle du ménage » CM, Pellerin (impresor, editor), Epinal. Circa 1870

Un marido "descalzoncillado", es decir, desautorizado, dominado, carente de respeto desde la perspectiva de la victimaria, tanto más cuanto la acción resulta ejemplar para la hija de la pareja. En el último grabado de la serie, hacia 1880, es la niña quien interviene en la "querelle", segura de que el poder conquistado se transmitirá a las mujeres de las siguientes generaciones: “

19 Cabe mencionar la tinta de Benedictus Van Assen, "Two scenes of a quarrel between husband and wife", c.1800, que integra la colección del Instituto Courtauld. La escena en la parte superior muestra a la pareja amenazándose con enseres de cocina mientras que la inferior describe el momento en que la mujer está a punto de golpear arteramente al marido dormido con un cepillo. Sitio: http://www.artandarchitecture.org.uk/images/gallery/32db0380.html 20 Las fechas de reimpresión son 1843, 1850, 1862, 1870 y 1880.

${ }^{21}$ "La grande querelle du ménage » CM, Pellerin (imprimeur, editeur), Epinal. Circa 1870. litografia coloreada sobre papel, Paris, Musée des Civilisations de l'Europe et de la Méditerranée. $\mathrm{N}^{\circ}$ inv. 50.39.2425 C 
Voyez cet heureux ménage/ quel doux tableau de marriage! [...] Papa, laisse la culotte à maman/ pour me revenir un jour en me mariant $"{ }^{22}$

Figura 7 - La grande querelle du ménage.

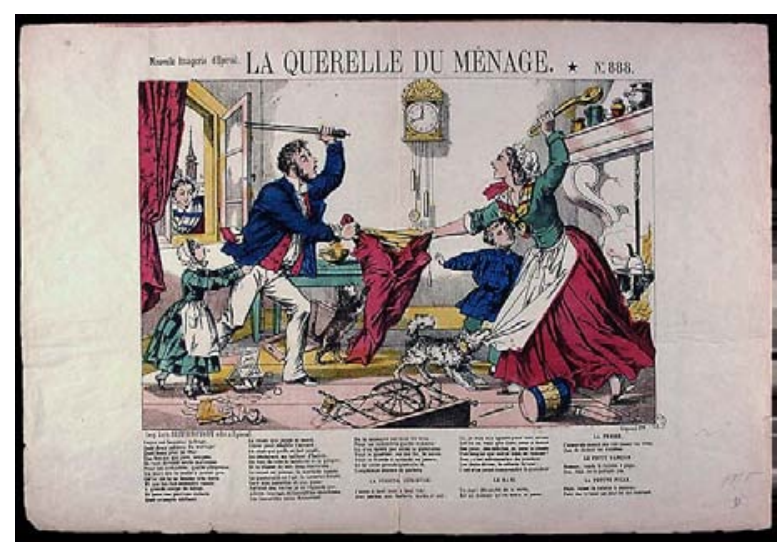

Fonte: « La grande querelle du ménage ", Olivier Pinot, (impresor, editor), Epinal. Entre 1875.y 1888.

Reconocemos en este combate el origen de un cliché de gran fortuna en la cultura popular, que ha llegado hasta nuestros días floreciendo en el terreno del humor gráfico y la comedia teatral, cinematográfica y televisiva. El tema se resume en una pregunta que, manifiestamente enunciada o sobreentendida en el contexto, apuntaba al corazón del argumento cómico: “¿quien lleva los pantalones en esta casa?". El lector seguramente evocará las ocasiones en que habrá reído frente a situaciones de disputa doméstica en diversos medios, aún mucho después de que nuestra historieta en cuestión se conociera en Buenos Aires, prueba del éxito de esta fórmula humorística a través del tiempo.

\section{Del teatro al diario y del diario al teatro}

Las funciones teatrales fueron a menudo fuente de inspiración para los dibujantes de comic-strips, especialmente a principios del siglo XX cuando el género se consolida. La velocidad de los tiempos de entrega que imponía la prensa diaria y la solicitud de historias y personajes

${ }^{22}$ " La grande querelle du ménage», Olivier Pinot, (imprimeur, éditeur) Epinal. Entre 1875.y 1888. Litografia coloreada sobre papel, Paris, Musée des Civilisations de l'Europe et de la Méditerranée. № inv. 50.39.2423 C. 
atractivos, forzaban a los cartoonists a la invención rápida de tiras que a veces no "pegaban" en los lectores y salían de circulación en un par de semanas. En este constante acicate para la "producción", los artistas debían echar mano a recuerdos o explotar al máximo la capacidad de agudos observadores de su propio entorno y en más de una ocasión, las veladas en el teatro de comedia y el varieté proporcionaron buenas ideas para la creación de historietas.

El mismo MacManus se inspiró en la obra The Rising generation que vio a fines de siglo en su Saint Louis natal. En la obra, se jugaba una partida de póker real cada noche y el protagonista, un obrero, -irlandés como el dibujante-, ganaba la suculenta suma en juego y se mudaba a la Quinta Avenida. El argumento impactó lo suficiente en MacManus para que diecisiete años más tarde, basara en ella la historia de Jiggs y su golpe de suerte, aunque en la tira difundida en Buenos Aires nunca se explicitó de dónde provino la fortuna.

Pero también el circuito se desarrollaba en sentido inverso: en el caso de Bringin'up father, su éxito en el diario lo catapultó a la escena, al celuloide y años más tarde, a las live-action series televisivas (HOLLOWAY, 2002) ${ }^{23}$, tan pronto como los patrocinadores de la tira advirtieron la posibilidad de transferir la fórmula cómica a otros medios y así multiplicar su rentabilidad económica, teniendo en cuenta que el dibujante quedaba fuera de los royalties. También en Buenos Aires historieta y comedia se potenciaron mutuamente. Una vez que la tira había calado en el público, la asistencia al teatro estuvo asegurada por el interés de ver a los personajes cobrar vida a través de los actores graciosamente caracterizados, exagerando un poco el modelo del cómic. Si en el papel, era la expresión gráfica ligada al texto lo que introducía el remate cómico ${ }^{24}$ (los garrotazos, el ojo morado), en el escenario se sacaba partido al contrapunto de los diálogos en que Trifón replicaba con una ingenuidad no exenta de ironía a las expresiones vulgares y amenazantes de Sisebuta. ${ }^{25}$

En 1925, la pieza "Trifón y Sisebuta" hizo estallar la taquilla del recientemente inaugurado Teatro Nuevo, completando doscientas funciones a sala llena. En la adaptación de Enrique García Velloso de la tira de La Nación, el autor diseñó un personaje a medida de Roberto Casaux, el gran

\footnotetext{
${ }^{23}$ En 1914 se estrenó la comedia musical en Broadway y el mismo empresario la produjo en casi todos los estados de la Unión. La última versión se estrenó en New York en 1928. El mismo Hearst, a través de su empresa International Film Service financió una serie de animaciones mudas en blanco y negro entre 1916 y 1918. En 1920 y 1921, la empresa patrocinó dos cortos animados y la MGM filmó en 1928 un largometraje mudo, siempre con producción de Hearst, cuyos protagonistas serían, según el anhelo del magnate, los famosos actores de vaudeville Joe y Myra Keaton, los padres de Buster, pero declinaron la oferta. Entre 1946 y 1950, Monogram Pictures, un estudio de producción y realización de films de bajo presupuesto, rodó cinco comedias, la más famosa "Bringin'up father in society (1947) con destacadas figuras del vaudeville de la época.

${ }^{24}$ No obstante, las traducciones han hecho perder la riqueza del lenguaje de los personajes, una suerte de slang que el dibujante expresaba con el acortamiento de palabras y el exceso de apostrofado que aportaba una dimensión humorística suplementaria para el público norteamericano. Quizás el Syndicate distribuía las tiras sin traducir, para que en cada país de habla castellana se adaptara a usos particulares del idioma. En Argentina, se empleó un castellano culto, sin voceo ni ningún modismo porteño, lo que hace sospechar si las tiras no llegaban ya traducidas de México.

${ }^{25}$ Sisebuta: (es su cumpleaños) “Sabes que día es hoy? /Trifón: Seguro. Es la fiesta de Duggan, prepara sopa de pescado. Puedo ir?/S: Insecto!!!!!. Me casé contigo para reformarte!/T: Lo lograste. Nunca me volveré a casar/S: Ojalá nunca te hubiera conocido.../T: Bueno, ahora que es demasiado tarde me compadeces". La Nación, 14 jun. 1922.
} 
actor cómico desaparecido en 1929, quien compuso una macchietta tan desopilante de Trifón, según la crítica de la época, que le valió un sitio de privilegio entre los grandes del "género chico", en tiempos en que Florencio Parravicini y Olinda Bozán eran los máximos referentes (SALZMAN, 2002, p. 281-299).

La pieza no sólo cifraba su éxito en la potencia humorística del temible estereotipo femenino sino también en la sátira sobre el snobismo y los artilugios urdidos por las mujeres en pos de conquistar status. En este sentido, la obra se inscribe en la línea de otras comedias teatrales que trataban el tema del ascenso social, pero con algunas diferencias respecto de las piezas de Florencio Sánchez o Gregorio de Laferrère diez años antes (PELLETIERI, 2002). Ya no se trataba de gente venida a menos que hacían lo indecible para "aparentar" sino de "nuevos ricos" tratando de asimilarse a los gustos y prácticas sociales de la upper-class. ${ }^{26}$ (ADAMOVSKY, 2009).

Juan A. García se cuenta entre los autores que explora "El Mundo de los Snobs" en su pieza homónima estrenada en 1920 y un año más tarde aparece Cuadros y caracteres snobs. Escenas contemporáneas de la vida argentina, novela que reúne los textos publicados por entregas en el diario La Prensa (GARCIA, 1921). Las descripciones de los ambientes ostentosamente decorados de la maison de los Benvenuto en la calle Quintana sugieren una écfrasis de las viñetas dibujadas por MacManus, obsesivamente detallista en los fondos, de líneas seguras y refinadas en clave Art Nouveau, a la manera de su gran inspirador Aubrey Beardsley:

El salón y el gran "hall", con su "parquet" lustroso, de un dibujo griego discreto [...] junto con los flamantes muebles, coquetos, amables, bonitos, algo incómodos para conversar con reposo y holgura, pero que constituían ricos adornos de ópera cómica de otros tiempos.[...] Por la puerta del fondo apareció Benvenuto, grueso, bonachón, risueño. [...] El cuadro era pintoresco y divertido, porque las personas, en contraste con los muebles y en armonía con la música, daban la impresión de un asalto para conquistar de pronto todos los refinamientos de la cultura. (GARCIA, 1921, p. 14-15). ${ }^{27}$

La novela semanal de García y la historieta de Trifón encuentran más de un punto de contacto. Desde las páginas de dos diarios de gran tirada, ambas producciones exploran el proceso de adaptación de los nouveaux riches a los gustos y comportamientos sociales de la clase

\footnotetext{
${ }^{26}$ En "Locos de verano" y "Las de Barranco" de Laferrere y "En familia" de Florencio Sánchez se trata de familias que han perdido su fortuna e intentan por distintos medios, inclusive los reñidos con la moral, recuperar la holgura económica. Similares en la trama y la estructura, las comedias de Federico Mertens, un popular autor teatral de principios del siglo XX, se centraban en la clase media. "Gente bien" (1909), "La carabina de Ambrosio" (1918) y "Clase media" (1928) transitan el mismo argumento.

${ }^{27}$ La cita alude al momento de la instalación de los Benvenuto, riquísimos estancieros recién llegados del campo, en el petit hotel, y de los preparativos para la gran cena baile donde presentarán a sus hijas en sociedad. A la fiesta asistirán algunos jóvenes de familias aristocráticas, con quienes intentaran casarlas. La itálica es nuestra.
} 
alta, un camino minado de frustraciones y que los lleva a rozar el ridículo con frecuencia. Como Sisebuta, aunque menos extrema en el comportamiento, la señora Benvenuto, en su afán por lograr status, también impone sus caprichos a un marido sencillo y resignado. El dibujante explota visualmente la comicidad de personajes y situaciones; el intelectual, con un humor más en sordina, deplora la decadencia cultural y el desafío al buen gusto encarnados, entre otros, por los advenedizos surgidos en tiempos de bonanza económica. Dibujantes y hombres de teatro supieron sacar provecho a las figuras del "snob" y la "mandona", cuando por entonces la fórmula humorística comenzaba a ser explotada en el cine silente. ¿Acaso Charlot no había sufrido los embates del palote de su monumental esposa, cuando regresa de madrugada al hogar miserable, habiéndose bebido el dinero del jornal?. ${ }^{28}$ Con certeza los argentinos habrán reído, casi en simultáneo con el público norteamericano, ante estas escenas que el cine mudo en la Argentina capitalizó desde su nacimiento (PUJOL, 1994, p. 101). ${ }^{29}$

En "La vuelta al bulín", cortometraje escrito y dirigido por José A. Ferreyra en 1926, se narran las desventuras de "Mucha espuma", un guapo del suburbio pero sólo en apariencia. Ambientado en espacios "tangueros" - el café, el cabaret- el hombre se ufana de "dominar mujeres" contando falsas historias hasta que llega "Pulguita", su concubina, presta a zurrarlo con el palo de amasar (VIEITES, 2009). El contraste entre los dichos del petulante guapo, y la expresión aterrorizada de sus ojos al enfrentar el "arma", desatan la risa colectiva. Sin trabajo y entretenido en el café, sólo ofrece privaciones a "Pulguita" quien, obnubilada por las promesas del próspero "Laucha colorada", abandona la pobre morada para vestirse de seda y bailar tango en un cabaret del centro. Ya sea en ambientes marginales o en el palacete del barrio chic, nuestras severas heroínas están unidas por el anhelo de ascenso social, verdadero núcleo del conflicto conyugal a partir del cual se contraponen los universos masculino y femenino: éste, el de los deseos nunca totalmente satisfechos que lleva a la intolerancia y la ofuscación; aquél, el de la resignación, la autocomplacencia y una buena dosis de indolencia.

Finalmente, entre "Pulguita" y "Mucha espuma" triunfa el amor, aunque todo parece indicar que no será por mucho tiempo.

\section{Trifón se escapa... a otras revistas}

Bien puede uno imaginar que el personaje de Trifón despertase en los lectores cierta ternura. El hombre, a fuerza de resistir sin perder un ápice de su buen humor, había ganado no solamente la solidaridad de sus congéneres sino también la simpatía de las lectoras que acaso

\footnotetext{
${ }^{28}$ Charles Chaplin, "Día de pago" (1922), First National Pictures. Agradezco a Guido Corbella la sugerencia de este film.

${ }^{29} \mathrm{Si}$ bien no se ha realizado todavía la lista de los films mudos estrenados en Buenos Aires, al parecer los de Chaplin se exhibían apenas unos meses más tarde de su estreno en Estados Unidos.
} 
vieran en Sisebuta un modelo de esposa con el que no querrían ser identificadas aunque, en su fuero íntimo, la idea de "llevar los pantalones" en el matrimonio resultara tentadora.

Tanto arraigaron estos caracteres en la vida cotidiana que, hacia mediados de la década, los apodos de Trifón o Sisebuta pasaron a integrar el lenguaje coloquial de los porteños, y a usarse habitualmente en las insípidas bromas de oficina. Ya en 1922, la revista "Páginas de Columba", fundada por el notable caricaturista político Ramón Columba, inaugura una sección dedicada a los recién casados: "Nuevos Trifones". Creada en complicidad con los lectores, los noveles matrimonios o sus familias, se prestaban a las chanzas de la revista enviando una fotografía de la boda sobre la que los dibujantes realizaban una caricatura, preanunciando con humor que la nueva condición de "marido" implicaba "obediencia ciega" a la cónyuge.

Figura 8 - Nuevos Trifones.

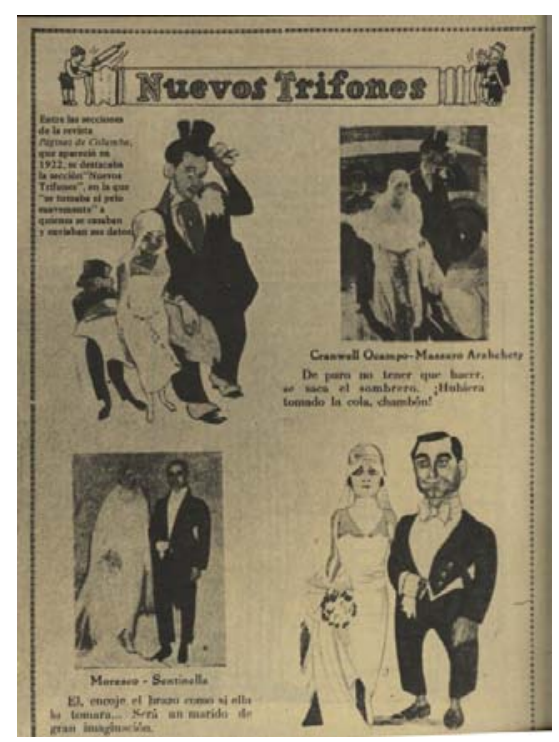

Fonte: “Nuevos Trifones”, Páginas de Columba, 1922

Los divertidos epígrafes ironizaban sobre la cuestión de que el romanticismo se diluye en el noviazgo y que una vez ingresado al bando de los casados, el varón tendría que vérselas con los caprichos de la esposa y los reproches de la suegra. Semejante horizonte de futuro era razón suficiente para que el casamiento se demorara a veces más de lo que la familia de la novia estaba dispuesta a tolerar (ARLT, 1931). ${ }^{30}$

La fama ganada por Trifón hizo que el personaje se emancipara de La Nación para "visitar" otras historietas. Interesante ejemplo de esta tournée es cuando en 1927 visita a Pantaleón

\footnotetext{
${ }^{30}$ Roberto Arlt consagra numerosas "aguafuertes" al tema del amor y el matrimonio, desde una visión crítica y pesimista de las relaciones entre hombres y mujeres, marcadas por el interés y la hipocresía.
} 
Carmona, protagonista de la tira aparecida ese año en la revista Femenil. ${ }^{31}$ Trifón, en su eterna fuga de Sisebuta y su palote, busca a su fiel amigo Pantaleón para tramar una coartada. ¿Cómo no auxiliarlo si Pantaleón corría aún peor suerte en su matrimonio, ya que, además de la esposa, también era aporreado por la suegra?

Figura 9 - Las andanzas de Pantaleón Carmona.

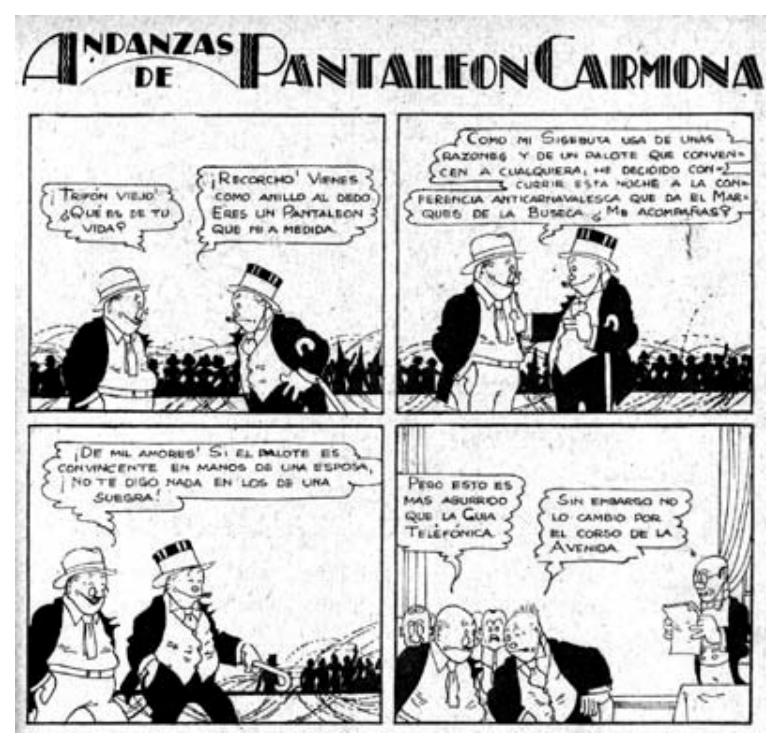

Fonte: "Las andanzas de Pantaleón Carmona”, Antonio Messa, Femenil, s/d, 1927

Es posible que el móvil para "tomar prestado" a Trifón haya sido una estrategia del humorista para potenciar la comicidad de su propia historieta y prestigiarse con la incursión de un desdichado tan "ilustre". En este sentido, la idea de "préstamos" entre las tiras con miras a crear una red de complicidades masculinas, no diversa de la efectivamente existente, resultaba sin duda un acierto de los humoristas por cuanto instalaba en los lectores el sentimiento de pertenencia a una comunidad de maridos victimizados, condición de la que podía sacarse algún provecho.

La obra de MacManus ejerció tal influencia en algunos dibujantes que comenzaron a aparecer historietas que reproducen, en ambientes vernáculos, el mismo argumento. El caso paradigmático es Las aventuras de Pancho Talero, creada por el dibujante Arturo Lanteri en 1922 para la revista El Hogar. La saga de Don Pancho, su esposa Petronila Cascallares y su hija Mechita es una versión aporteñada de la norteamericana, una copia, si se quiere, de las situaciones y la

31 “Las andanzas de Pantaleón Carmona” de Antonio Messa en 1927. 
estructura narrativa y, desde el punto de vista visual, de las fisonomías de los personajes: el hombre, bajo y regordete, de talero al cinto que no se quita ni aún en pijamas, la mujer, de fuerte carácter, que lo duplica en altura y volumen y la jovencita preocupada por la última moda y por casarse con alguien de buena posición.

Figura 9 - Las aventuras de Pancho Talero.

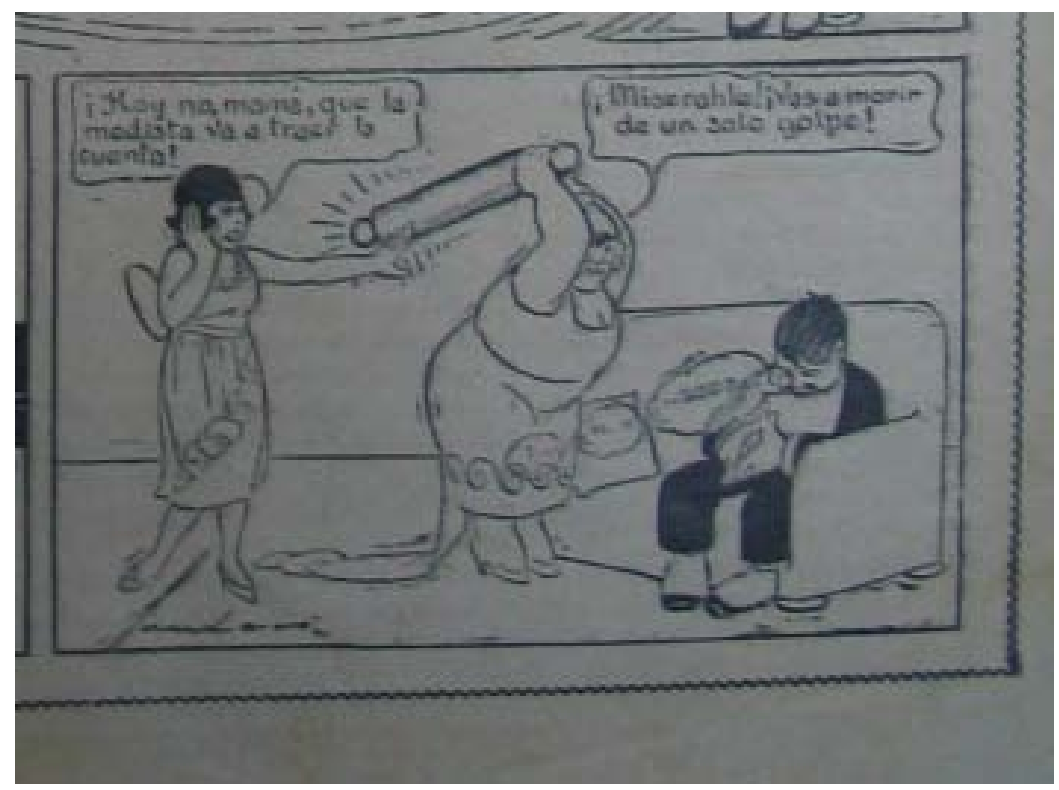

Fonte: "Las aventuras de Pancho Talero", El Hogar, 28 abr. 1922

Poco puede decirse acerca de la tira de Lanteri que no haya sido ya comentado respecto de la de MacManus. El argumento gravita esencialmente sobre los mismos tópicos ya que Pancho es tan víctima del palote como Trifón y Petronila tan snob como Sisebuta. Las diferencias estriban en la ambientación en espacios rápidamente reconocibles para los lectores de Buenos Aires, la utilización de un lenguaje "acriollado", la vestimenta campera y el consumo compulsivo de puchero que acortaban distancias con el público porteño, posibilitando una mayor identificación con Pancho que con Trifón, mientras que Petronila y Sisebuta cultivaban la imagen de modernas mujeres cosmopolitas. 
Figura 10 - Las aventuras de Pancho Talero.

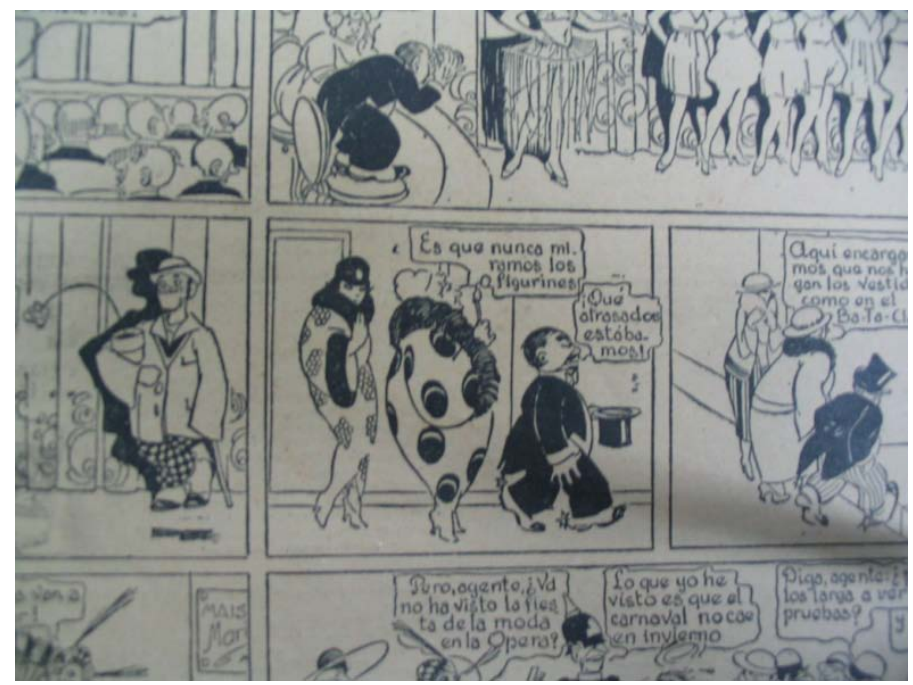

Fonte: "Las aventuras de Pancho Talero", El Hogar, 22 jun. 1922

El hecho de publicarse en la aristocrática El Hogar agrega significados suplementarios. A quien hojee la revista, se le impone el contraste entre las viñetas de la familia de nuevos ricos y las fotografías de las señoritas de sociedad, impresos en páginas contiguas: a un lado, la clase alta real, en poses artificiosas y ambientes sofisticados; en el otro, las Talero, ataviadas al borde de lo tolerable por el buen gusto, recriminando al hombre, entre tantas otras cosas, su vestimenta vulgar. En este sentido, la tira humorística dialoga con las notas un tanto ligeras de la revista, y pone en evidencia, quizás desde nuestra mirada actual, las grietas entre el universo de la upper class y los parvenus, nunca totalmente aceptados por la gran sociedad. Pero aunque El Hogar estaba destinada a las niñas "bien" de la élite y a sus madres, circulaba, sobre todo, entre muchachas de clase media "con aspiraciones" que buscaban en las fotos y en las notas de modas los modelos para sus propios atuendos. Así, la historieta funcionaba en cierta medida como espejo del comportamiento de quienes no eran del todo concientes de sus deseos y actitudes.

La familia de Don Pancho, como la de Trifón, pronto se granjeó la simpatía de los lectores y sus graciosas fisonomías acicateaban la imaginación en tiempos de Carnaval ${ }^{32}$. No eran pocos los que optaban por disfrazarse de alguno de los personajes, o de la familia completa. Justamente, el dibujo a color de Lanteri para la portada de El Hogar que muestra a "Pancho Talero y los suyos" desfilando en una carroza, inspiró numerosas máscaras en todos los corsos de la República y el público respondió atiborrando de fotografías la redacción de El Hogar.

\footnotetext{
${ }^{32}$ En 1932, los imponentes muñecos de Trifón y Sisebuta de 4,50 $\mathrm{m}$ de alto, hechos en cartapesta policromada fueron las
} estrellas del carnaval de Lincoln. "Museo Urcola", Lincoln, Pcia. De Buenos Aires. 


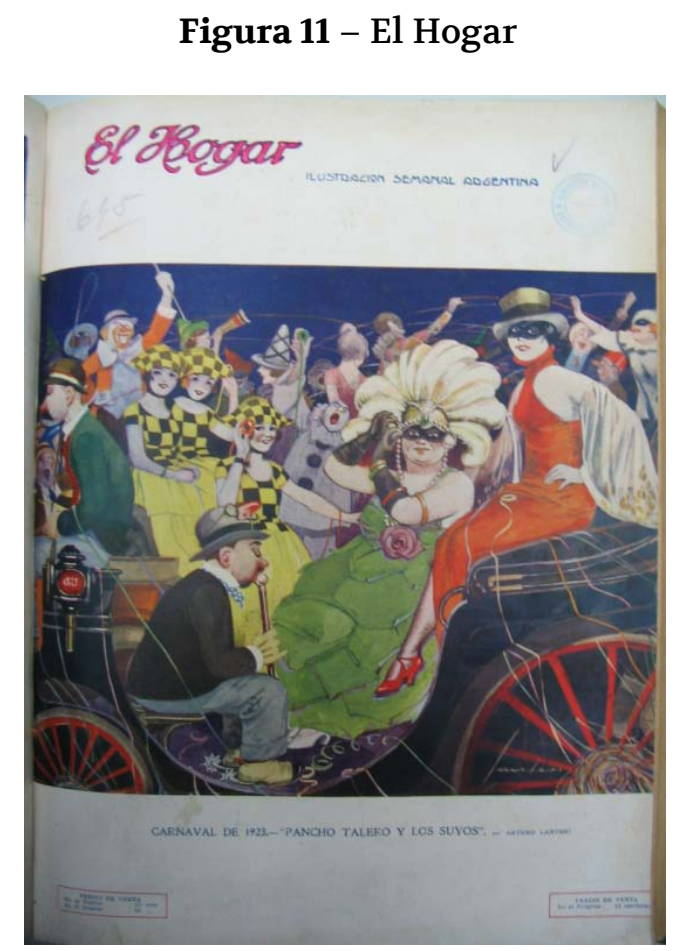

Fonte: Carnaval de 1923, Portada El Hogar

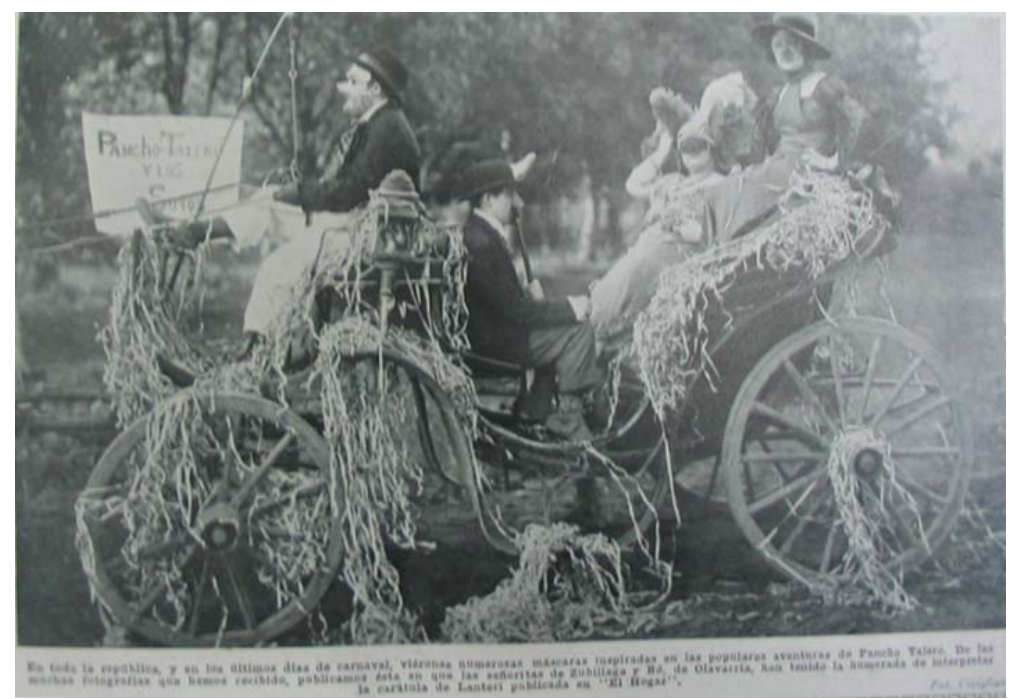

Fonte: Fotografía del corso de Olavarría, El Hogar, 1923 
Si algún otro paralelo puede trazarse entre estas historietas, es la proyección que ambas tuvieron fuera del diario y la revista. La popularidad de Talero impulsó a su creador, hacia fines de la década, a probar suerte en el negocio cinematográfico. El cine permitía la circulación amplia de la ya conocida saga humorística en todo el país y así Lanteri se lanzó a la producción y realización de tres películas: la primera en 1929, con el mismo título que la tira; al año siguiente "Pancho Talero en la prehistoria"-ambas mudas- y la sonora "Pancho Talero en Hollywood", estrenada en 1931 en medio de una eufórica campaña publicitaria.33 Por entonces, la fabricación de muñecos de cerámica de las dos parejas, de unos $18 \mathrm{~cm}$. (las señoras, por supuesto, más altas) son muestra del interés de los seguidores de la tira por atesorar estos objetos kitsch como decoración del hogar.

Figura 12 - Muñecos de cerámica

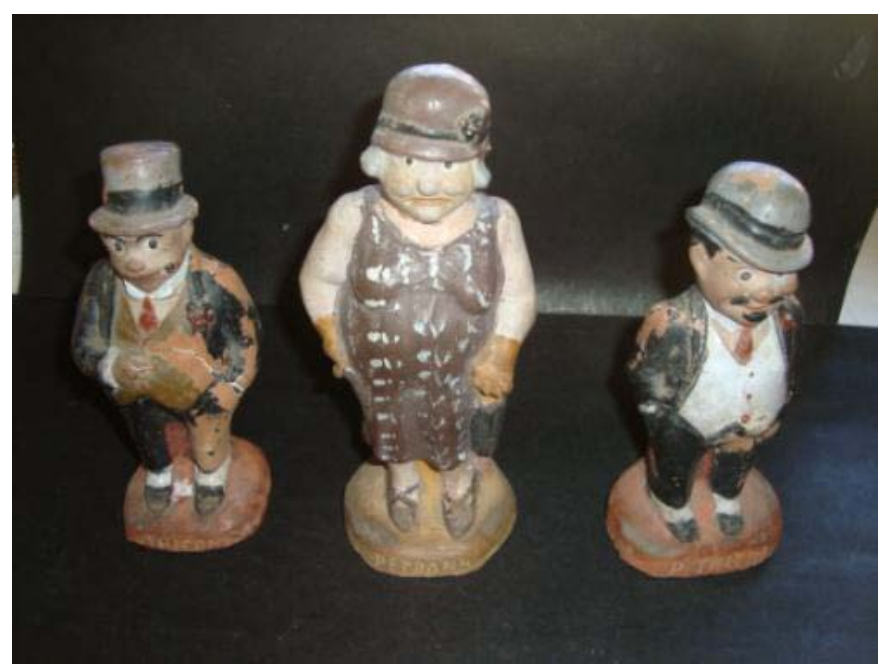

Fonte: Muñecos de cerámica: Trifón, Petronila y Don Pancho

Las aventuras de Pancho..., como su modelo, Pequeñas delicias... hicieron escuela entre los humoristas argentinos, dando origen a varias historietas con la misma matriz. Además Las andanzas de Pantaleón Carmona, en 1925 Arístides Rechain crea para La Novela Semanal, La familia de don Sofanor, cuyo protagonista, por cierto bastante corrupto, no escapa a las imposiciones de su esposa pero comparte con ella las veleidades de asimilarse a la clase alta. Los ejemplos de family strips en los años veinte podrían, por cierto, extenderse, y si avanzáramos en el tiempo, encontraríamos unos cuantos epígonos de Trifón ¿acaso la vida matrimonial no resultaba un

\footnotetext{
33 "Siete grandes actos de humor, donde los personajes de una conocida historieta se mueven al antojo de su autor. Film sonoro, hablado, cantado con música [...] llevado a la pantalla a todo costo y lujo de detalles", Tomado del volante publicitario del film. Museo Municipal del Cine "Pablo Ducrós Hicken". De las tres películas sólo se conservan 9 minutos de "Pancho Talero en Hollywood". Colección MALBA.
} 
flagelo para el Señor López ${ }^{34}$ ? ¿y Eulogia, la mujer de Inodoro Pereyra, aquella cuya mirada azabache lo atravesó como un rayo alguna vez, no se transformó en la mujerona de trato áspero capaz de jaquear al gaucho cuando llegaba tarde?

Sisebutas, Petronilas, señoras Benvenuto: fierecillas nunca domadas, herederas del mal genio de tantas otras mujeres de ficción a lo largo de los siglos, han divertido a generaciones de argentinos sobre el diario calvario de sus maridos.

Asumiendo que las historietas son objetos culturales, hemos recurrido en nuestro análisis a herramientas metodológicas de la historia cultural, esto es, examinarlas en la encrucijada de dos dimensiones temporales -los ejes sincrónico y diacrónico señalados por Carl Schorske-, así como al enfoque warburguiano en el rastreo de estas fórmulas expresivas y significantes en la vida de las sociedades. En esta trayectoria plurisecular, el topos humorístico de la "lucha por los calzoncillos" ha resurgido en nuestras historietas de los albores del siglo XX, revelando su vitalidad y permanencia en la cultura occidental.

En este sentido, hemos tomado distancia del enfoque semiótico que ha prevalecido desde hace unas cuantas décadas, tendiente a circunscribir el análisis a los aspectos del lenguaje, para proponer la aplicación de una perspectiva teórica propia de los estudios de historia del arte al estudio de un tipo de objetos de reproducción y circulación masiva y de consumo popular como la historieta. Creemos que el planteo de un análisis de estas características ha permitido poner de manifiesto las contribuciones de la historieta a la esfera de las sensibilidades colectivas, por cuanto induce, satirización mediante, a la reflexión sobre modelos de comportamiento sociales, relaciones de género, sin olvidar, en las transferencias de situaciones de ficción a la vida cotidiana, sus aportes al lenguaje popular.

Una palabra más. Hemos llegado al final del capítulo y no hemos aludido al amor. Sisebutas hubo siempre, pero el rigor del palote no alcanzó a mitigar la ternura que le inspiraban los esposos, aun cuando, entre caricias y abrazos, el grito de “iiinsecto!!!” podía filtrarse repentinamente. A pesar de todo, hay que imaginar a los Trifones dichosos.

\section{Referencia}

ADAMOVSKY, Ezequiel. Historia de la clase media argentina: apogeo y decadencia de una ilusión (1919-2003). Buenos Aires: Planeta, 2009.

ARLT, Roberto. El Calientasillas. In: Aguafuertes porteñas. El Mundo, Buenos Aires, 14 ago. 1931.

\footnotetext{
34 "Las puertitas del Señor López", Carlos Trillo (guión) y Horacio Altuna (dibujos). Publicada en 1979 en El Péndulo, pasó poco después a la revista Humor, hasta 1982. López es el caso extremo de hombre dominado, no solamente por su mujer.
} 
BERGER, Peter. Risa redentora: la dimensión cómica de la experiencia humana. Madrid: Kairós, 1999.

BURUCÚA, José Emilio. Corderos y elefantes: la sacralidad y la risa en la modernidad clásica siglos XV a XVII. Buenos Aires: Miño y Dávila, 2001.

. La imagen y la risa: La Pathosformel de lo cómico en el grabado europeo de la modernidad tardía. Madrid: Periférica, 2007.

Para una búsqueda de las Pathosformeln de lo cómico en el grabado europeo de la modernidad temprana. In: JORNADAS DE HISTORIA, ARTES, MEMORIA Y POLÍTICA, 5., 2005, Buenos Aires. Anales... Buenos Aires: Universidad Torcuato Di Tella, 2005.

CHARTIER, Roger. El mundo como representación: historia cultural: entre practica y representación. Barcelona: Gedisa, 1992.

CHAUCER, Geoffrey. El cuento de la comadre de Bath: Canterbury Tales, fines del siglo XIV. 1484. Disponible en: <http://literatura.itematika.com/libro/375/cuentos-de-canterbury.html>. Acceso en: out. 2010.

GARCÍA, Juan Agustín. Cuadros y caracteres snobs: escenas contemporáneas de la vida argentina. Buenos Aires: Editorial Gath y Chaves, 1923.

GOMBRICH, Ernst. El arsenal del caricaturista. In: . Meditaciones de un caballo de juguete. Barcelona: Seix barral, 1967.

HARVEY, Robert. The art of the funnies: an aesthetic history. Oxford: University Press of Mississippi, 1994.

HOLLOWAY, Clark. The Holloway pages. Bringing up father. 2002. Diponible en: <http://home.comcast.net/ cjh5801a/Jiggs.htm>. Acceso en: set. 2010.

KOENIGSBERG, Moses. King News: an autobiography. Florida: New world manufacturing Co.\& Inc, 1941.

PELLETIERI, Osvaldo (Ed.). Historia del teatro argentino en Buenos Aires. Buenos Aires: Galerna, 2002. (La emancipación cultural, v. 2).

PUJOL, Sergio. Valentino en Buenos Aires: los años veinte y el espectáculo. Buenos Aires: Emecé, 1994.

RABELAIS, François. Le tiers livre des faicts et dicts hérö̈ques du noble Pantagruel. Paris, 1546.

SALZMAN, Isidro. Roberto Casaux. In: PELLETIERI, Osvaldo (Ed.). Historia del teatro argentino en Buenos Aires. Buenos Aires: Galerna, 2002. (La emancipación cultural, v. 2).

SCHORSKE, Carl. Viena in-de-siècle: política y cultura. Barcelona: Gustavo Gili, 1981.

SKAKESPEARE, William. The taming of the Shrew: escrita presumiblemente entre 1590 y 1594. Madrid: Edaf, 2002. 
VERGUEIRO, Waldomiro. As histórias em quadrinhos e seus gêneros IV: os quadrinhos em ambiente familiar. InfoHome, Outubro, 2003. Não está no gibi. Disponible en: < http://www.ofaj.com.br/colunas_conteudo.php?cod=145>. Acceso en: dec. 2010.

VIEITES, Mary. La vuelta al bulín. In: FÉLIX-DIDIER, Paula; PEÑA, Fernando M. Colección Mosaico criollo. Primera antología del cine mudo argentino. Buenos Aires: INCAA, 2009.

WARBURG, Aby. El renacimiento del paganismo: aportaciones a la historia cultura 1 del renacimiento europeo. Madrid: Alianza Editorial, 2005.

Recebido em 30/02/2012

Aprovado em 30/05/2012 